\title{
A!
}

This is an electronic reprint of the original article.

This reprint may differ from the original in pagination and typographic detail.

Sairanen, Marjo; Selonen, Olavi

\section{Dust formed during drilling in natural stone quarries}

Published in:

Bulletin of Engineering Geology and the Environment

DOI:

10.1007/s10064-017-1016-5

Published: 01/08/2018

Document Version

Peer reviewed version

Please cite the original version:

Sairanen, M., \& Selonen, O. (2018). Dust formed during drilling in natural stone quarries. Bulletin of Engineering Geology and the Environment, 77(3), 1249-1262. https://doi.org/10.1007/s10064-017-1016-5

This material is protected by copyright and other intellectual property rights, and duplication or sale of all or part of any of the repository collections is not permitted, except that material may be duplicated by you for your research use or educational purposes in electronic or print form. You must obtain permission for any other use. Electronic or print copies may not be offered, whether for sale or otherwise to anyone who is not an authorised user. 


\section{Dust formed during drilling in natural stone quarries}

Marjo Sairanen, $1,{ }^{*}$
Phone +358440660248
Email marjo.sairanen@gmail.com

Olavi Selonen, 2

Email olavi.selonen@abo.fi

1 Department of Civil Engineering, Aalto

University, 00076 Helsinki, Finland

${ }^{2}$ Faculty of Science and Engineering, Geology and Mineralogy, Åbo Akademi University, 20500 Turku, Finland

\section{Abstract}

Dust mass concentration and concentration decrease was studied in two natural stone quarries in Finland. The dust mass concentrations produced during drilling was measured at several distances with short time interval $(5 \mathrm{~s})$ sampling. The variation of concentration was high, and wind direction had a crucial effect on dust dispersion. The impact of weather conditions, such as temperature and relative humidity, on dust concentration were inconsistent. The dust produced during drilling was mainly coarse-grained and it settled quickly. The background mass concentration was attained from 55 to $105 \mathrm{~m}$ at the downwind direction from the drill. The fine particle mass concentrations were low during the measurements. The fine particles originated mainly from other, remote, sources and from the machinery used in the quarries. Local dust sources, such as hauling, had a significant impact on dust mass concentrations 
even inside the quarry. The drilling capacity effected on dust mass concentration near the drill, but the impact vanished quickly with increasing distance.

\section{Keywords}
Drilling
Dust mass concentration
Open pit quarry
Natural stone
Finland

\section{Introduction}

Dust is a generic term describing fine, solid particles that are suspended in the atmosphere. Dust is in the micrometer range or larger (Hinds 1999). Total suspended particles (TSP) have relatively coarse size range. TSP size range varies from 10 to $100 \mu \mathrm{m}$, but a $30-\mu \mathrm{m}$ aerodynamic diameter is commonly applied (US EPA 1995). $\mathrm{PM}_{10}$ and $\mathrm{PM}_{2.5}$ standards involve particulate matter with an aerodynamic diameter of $10 \mu \mathrm{m}$ or less and of $2.5 \mu \mathrm{m}$ or less, respectively. $\mathrm{PM}_{2.5}$ is usually referred to as fine particles (US EPA 1995) and $\mathrm{PM}_{10}$ or larger particles to coarse particles. According to the Office of the Deputy Prime Minister, England (2003) particles over $30 \mu \mathrm{m}$ form the greatest proportion of dust concentration emitted from mineral workings, such as quarries, and will deposit within $100 \mathrm{~m}$ from the source. Intermediate sized particles $(10-30 \mu \mathrm{m})$ are likely to travel up to 200-500 m. Smaller particles (less than $10 \mu \mathrm{m}$ ) represent a small proportion of dust and are deposited slowly (Office of Deputy Prime Minister 2003).

Dust is an environmental issue at many quarries and the most dust producing process in natural stone quarries is drilling (Organiscak and Page 2005; Sairanen 2014). Dust produced during the drilling has decreased during the recent years due to the dust control systems which are today commonly applied (Romu 2014). Blasting produces a dust plume 
which spreads over quarry area with the prevailing wind. The quarry area itself and hauling are also significant dust sources (Reed 2003 ), especially during dry and windy weather conditions.

Dust exposure may correlated with serious health risk. Health effects resulting from exposure to different types of dust include, for example pneumoconiosis, cancer, irritation, and allergic responses such as asthma (World Health Organization 1999). Particle size is directly linked to the potential to cause health problems. Small particles below $10 \mu \mathrm{m}$ in diameter pose the greatest problems when penetrating deep into lungs and even into bloodstream (US EPA 2013 ).

Dust particles from quarry operations are observed to have elongated morphology (e.g. Junttila et al. 1997; Hedges 2016). According to Räisänen (2004) the relative proportions of minerals in stone material are not the same as their proportions in the $\mathrm{PM}_{10}$ dust, whereas Belardi et al. (2013) observed some correlation between size and morphology of particles and petrographic rock properties. Crystalline silica and quartz have been associated to harmful health effects in several studies (e.g. Madl et al. 2008). Dust formed during the drilling, e.g. in a marble quarry contained approximately $0.2-0.6 \%$ crystalline silica (Golbabaei et al. 2004 ). Hedges (2016) observed that the finer the respirable dust particles the greater proportion of the finer particles, which are crystalline silica.

Dust measurements made in open pit quarries has yielded highly variable results (e.g. Sairanen et al. 20162017 ). The manuscript was published online 5th of January in 2017. Article is still in press. Therefore, studies with similar study setup in varying types of quarries are needed to better understand dust production, concentration variation and dust concentration decrease with increasing distance (i.e. dust retention). This study aims to assess dust production and emission dispersion from rock drilling operation in open pit quarries. This is to achieve a better understanding of dust mass behaviour. Such knowledge is needed to evaluate environmental impact and to prevent harmful effect caused by drilling. Quarrying requires environmental permitting and, therefore, sufficient knowledge of dust and 
its dispersion is needed among quarry operators and public officers to ensure the acceptability of the quarrying.

The study was conducted in natural stone quarries, because the amount of drilling is higher compared to, e.g. mining and aggregate quarrying. This paper is framed around the following sub-topics. Firstly, the dust mass concentration produced during the drilling is evaluated from the measurements. Secondly, the differences between the different drill types producing dust, is compared. Thirdly, the impacts of weather conditions (temperature, relative humidity, wind speed) to the dust concentration are discussed. Finally is assessed the retention of dust mass concentration and the distance where background mass concentration is achieved. The health effects caused by dust are excluded in this paper.

\section{Previous studies}

Dust measurements in real operating conditions are demanding due to the large amount of variables affecting on dust concentration. The weather conditions, especially wind, have a crucial impact on dust concentration and the dust spreading area. According to previous studies the dust produced during the quarrying consist of coarse particles, which settle near the dust source (Office of Deputy of Prime Minister 2003). However, some studies suggest that the dust particles are spread several kilometres away from the quarries (e.g. Cattle et al. 2012).

The knowledge of dust emissions from quarries is limited and consistency of results is low. A number of studies (Organiscak and Page 1995; Junttila et al. 1996; Aatos 2003; Golbabaei et al. 2004; Organiscak and Page 2005; Olusegun et al. 2009; Bada et al. 2013; Degan et al. 2013;

Sairanen 2014) have emphasis on dust formation during the drilling. Dust concentrations from drilling varied between approximately 100 $-110,000 \mu \mathrm{g} \mathrm{TSP} / \mathrm{m}^{3}$ (Sairanen et al. 20162017 ). The manuscript was published online 5th of January in 2017. Article is still in press.

According to Organiscak and Page (1995), TSP caused by drilling varied between 500 and $95,000 \mu \mathrm{g} / \mathrm{m}^{3}$ for ten different drills. Three of these drills 
had dust control systems having a TSP concentration between 800 and $2000 \mu \mathrm{g} / \mathrm{m}^{3}$. The measurements were conducted downwind from 12.2 to $30.5 \mathrm{~m}$ of the drill (Organiscak and Page 1995). In a study by Organiscak and Page (2005) drilling produced TSP only 180 and $110 \mu \mathrm{g} / \mathrm{m}^{3}$, when dust prevention technique was applied. The measurements were conducted in real operating conditions next to the drill table (Organiscak and Page 2005 ). In a natural stone quarry in Finland at $50 \mathrm{~m}$ distance from the production site the observed $\mathrm{PM}_{10}$ and $\mathrm{PM}_{2.5}$ concentrations were approximately 80 and $20 \mu \mathrm{g} / \mathrm{m}^{3}$, respectively (Aatos 2003 ).

Drilling in open pit quarry, where also other quarrying processes (crushing) appeared, had significantly higher dust concentrations: approximately $5000 \mu \mathrm{g} \mathrm{PM}_{10} / \mathrm{m}^{3}$ (Degan et al. 2013), on average $14,000 \mu \mathrm{g} \mathrm{TSP} / \mathrm{m}^{3}$ (Junttila et al. 1996) and approximately $16,000 \mu \mathrm{g}$ $\mathrm{PM}_{10} / \mathrm{m}^{3}$ (Olusegun et al. 2009). The highest reported concentrations were measured in natural stone quarry in Iran, where TSP and $\mathrm{PM}_{10}$ concentrations varied 78,000-110,000 and 6000-11,000 $\mu \mathrm{g} / \mathrm{m}^{3}$, respectively (Golbabaei et al. 2004).

The measurements made in granite quarries in Nigeria (Bada et al. 2013) and in Finland (Sairanen 2014) gained dust mass concentrations same order of magnitude near the drilling. TSP concentrations were few hundreds of micrograms per cubic meter and $\mathrm{PM}_{2.5}$ concentrations were few tens of micrograms per cubic meter in both studies. $\mathrm{PM}_{10}$ concentrations had more variation being approximately $70 \mu \mathrm{g} / \mathrm{m}^{3}$ in study reported by Bada et al. (2013) and varying between 60 and $670 \mu \mathrm{g} / \mathrm{m}^{3}$ in study reported by Sairanen (2014). However, the ambient concentrations measured in Nigeria were significantly higher (approximately ten times or more) than ambient concentrations in Finland even though sampling distance were significantly higher $(5000 \mathrm{~m})$ in the study conducted in Nigeria compared to the ambient sampling distances (few tens of meters) in the study conducted in Finland.

\section{Quarrying of natural stone}


According to the European standard EN 12670 (2001) (Natural stone-Terminology) natural stone is defined as a piece of naturally occurring rock. A natural stone product is a worked piece of naturally occurring rock used in buildings and for monuments. Natural stone is cut out of solid rock into large solid rectangular blocks with definite dimensions and sizes. The blocks are further processed by sawing and splitting into final products with different surface finishes. Dimension stone and facing stone are other terms often used synonymously for natural stone in architectural purposes.

The Finnish granite quarrying is a mechanized process done by specialized machinery (Selonen and Heldal 2003; Vuolio and Halonen 2010; Salmela et al. 2014). Techniques used comprise precision drilling, smooth blasting, wedging, and diamond wire sawing. The first stage of extraction comprises loosening of the primary block of size from 100 to $4000 \mathrm{~m}^{3}$. At the back of the primary block a line of vertical holes (4-6 m deep) and at the bottom 6 $-8 \mathrm{~m}$ long horizontal holes are drilled with hydraulic drilling machines.

The distances between holes are in average $30 \mathrm{~cm}$. Both the vertical and horizontal holes are charged and blasted with plastic cartridges (K-pipes) with a low average charge density. The detached primary block is subdivided into smaller blocks, which are further shaped into final sizes and dimensions, mainly by drilling and hydraulic splitting. The final product of the quarry is a stone block with a definite size and shape.

\section{Materials and methods}

\section{Quarries and production devices}

Measurements were conducted in two natural stone quarries in Finland. The quarry $\mathrm{A}$ is the largest natural stone quarry in Finland with a monthly production of approximately $1800 \mathrm{~m}^{3}$ and the quarry B represents an average Finnish natural stone quarry with a monthly production of approximately $300 \mathrm{~m}^{3}$.

The rock of the quarry $\mathrm{A}$ is a brown porphyritic, coarse-grained rapakivi granite with a typical rapakivi texture of round $1-3 \mathrm{~cm}$ potassium feldspar 
ovoids with a plagioclase mantle. The main minerals are potassium feldspar, plagioclase, quartz, amphibole, and biotite (Härmä and Selonen 2008; Härmä et al. 2015) (Table 1).

\section{Table 1}

Properties of the rock types

(Source: Geological Survey of Finland)

\begin{tabular}{|l|l|l|}
\hline Mineral content/technical properties & Quarry A & Quarry B \\
\hline Amphibole & $7.3 \mathrm{wt} \%$ & - \\
\hline Biotite & $4.8 \mathrm{wt} \%$ & $5.2 \mathrm{wt} \%$ \\
\hline K-feldspar & $26.9 \mathrm{wt} \%$ & $39.6 \mathrm{wt} \%$ \\
\hline Muscovite & - & $1.3 \mathrm{wt} \%$ \\
\hline Plagioclase & $36.9 \mathrm{wt} \%$ & $22.2 \mathrm{wt} \%$ \\
\hline Quartz & $23.1 \mathrm{wt} \%$ & $30.1 \mathrm{wt} \%$ \\
\hline Accessory minerals & $2.0 \mathrm{wt} \%$ & $1.8 \mathrm{wt} \%$ \\
\hline Water absorption & $0.10 \%$ & $0.12 \%$ \\
\hline Apparent density & $2680 \mathrm{~kg} / \mathrm{m}^{3}$ & $2640 \mathrm{~kg} / \mathrm{m}^{3}$ \\
\hline Flexural strength & $9.1 \mathrm{MPa}$ & $13.4 \mathrm{MPa}$ \\
\hline Frost resistance (change of flexural strength) & $-4.4 \%$ & $-3.7 \%$ \\
\hline Compressive strength & $162 \mathrm{MPa}$ & $171 \mathrm{MPa}$ \\
\hline Abrasion resistance & $17 \mathrm{~mm}$ & $17 \mathrm{~mm}$ \\
\hline
\end{tabular}

The rock of the quarry B is a medium-grained red porphyritic rapakivi granite mainly composed of potassium feldspar, quartz, plagioclase, and biotite (Lindberg and Bergman 1993; Selonen et al. 2005, 2011) (Table 1 ). The porphyritic texture of the granite is defined by potassium feldspar phenocrysts ( $\leq 2 \mathrm{~cm}$ in length). A few potassium feldspar ovoids can be found. 
Both quarries had following processes running during the dust measurements: drilling, blasting, hydraulic splitting and hauling of stone blocks and leftover stone.

There were two drill types employed in the quarries during the study (Table 2). Drill type 1 (D1) was specially modified from a forest machine to meet the needs of the natural stone production. The drill type 2 (D2) was a commercial drill with higher drilling capacity compared to D1. Drilling was conducted both vertical (V) and horizontal (H) directions (Fig. $1 \mathrm{a}, \mathrm{b}$ ). All drills were equipped with dust control systems which functioned properly during the measurements.

\section{Table 2}

Drill types in operating during measurements

\begin{tabular}{|c|c|c|c|}
\hline $\begin{array}{l}\text { Drill } \\
\text { type }\end{array}$ & $\begin{array}{l}\text { Drilling } \\
\text { direction }\end{array}$ & $\begin{array}{l}\text { Drilling capacity } \\
(\mathrm{m} / \mathrm{s})\end{array}$ & Other properties \\
\hline D1V & Vertical & 0.14 & $\begin{array}{l}\text { Modified from forest } \\
\text { machine }\end{array}$ \\
\hline $\mathrm{D} 2 \mathrm{~V}$ & Vertical & 0.22 & Commercial drill \\
\hline $\mathrm{D} 1 \mathrm{H}$ & Horizontal & 0.14 & $\begin{array}{l}\text { Modified from forest } \\
\text { machine }\end{array}$ \\
\hline
\end{tabular}

\section{Fig. 1}

a Vertical drilling with commercial drill (D2V). b Horizontal drilling with drill modified from forest machine (D1H) and sampling at downwind (DW) direction at $5 \mathrm{~m}$ distance and at side-wind (SW) direction at $10 \mathrm{~m}$ distance 


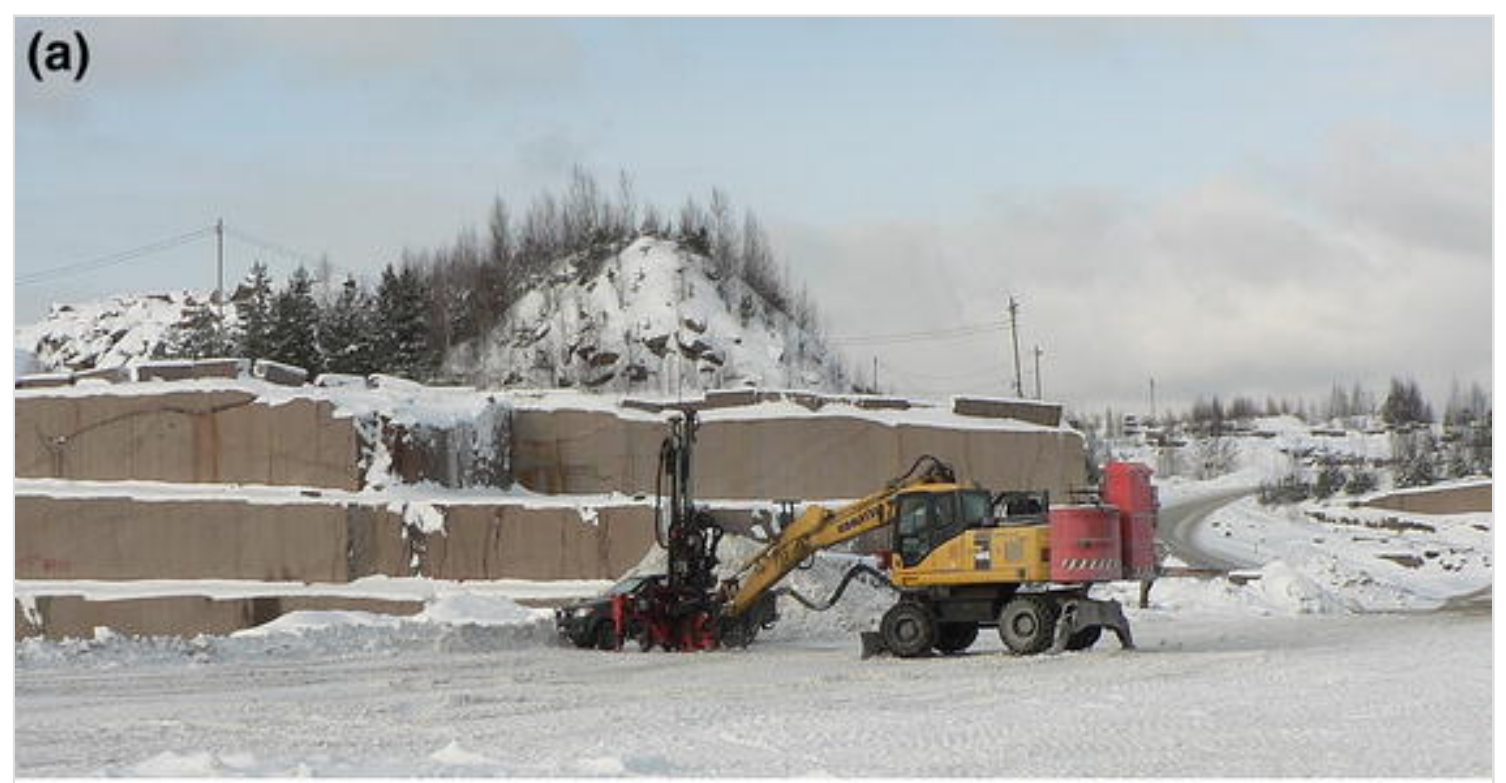

(b)

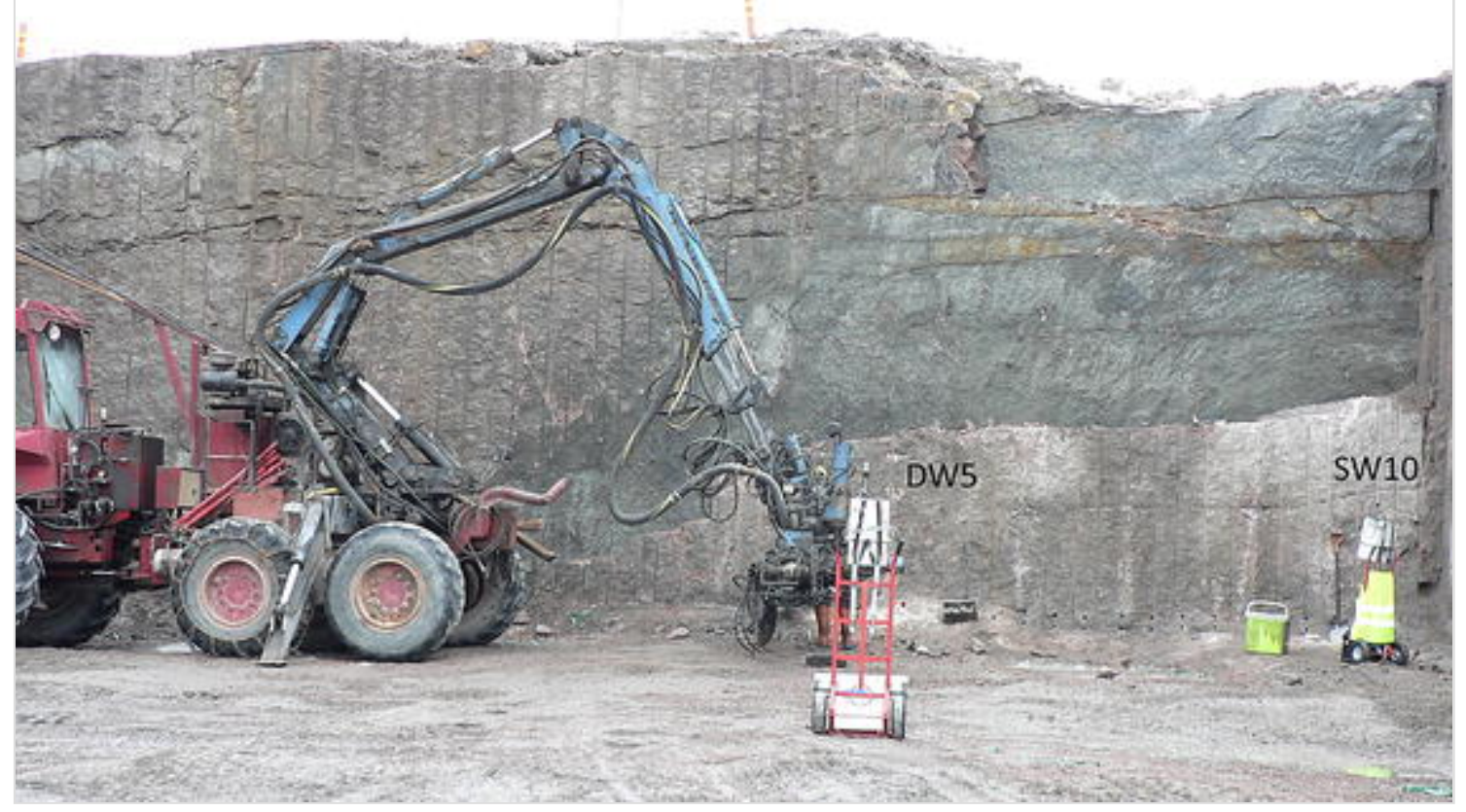

\section{Sampling equipment and duration}

Measurements were conducted with two Turnkey Osiris nephelometers (Fig. 2a). Nephelometer records continuously and simultaneously particles mass fraction. It detects the light scattered from airborne particles. The scattered light consists of three components: reflection, refraction, and diffraction. The diffracted component depends only on the size of the particle. Osiris nephelometers analyse the light scattered through $10^{\circ}$ or 
less to respond only to the diffracted component (Turnkey Instruments Ltd 2014) (Fig. 2b).

\section{Fig. 2}

a Osiris nephelometer. $\mathbf{b}$ The nephelometer operating principle (modified from Turnkey Instruments Ltd 2014)

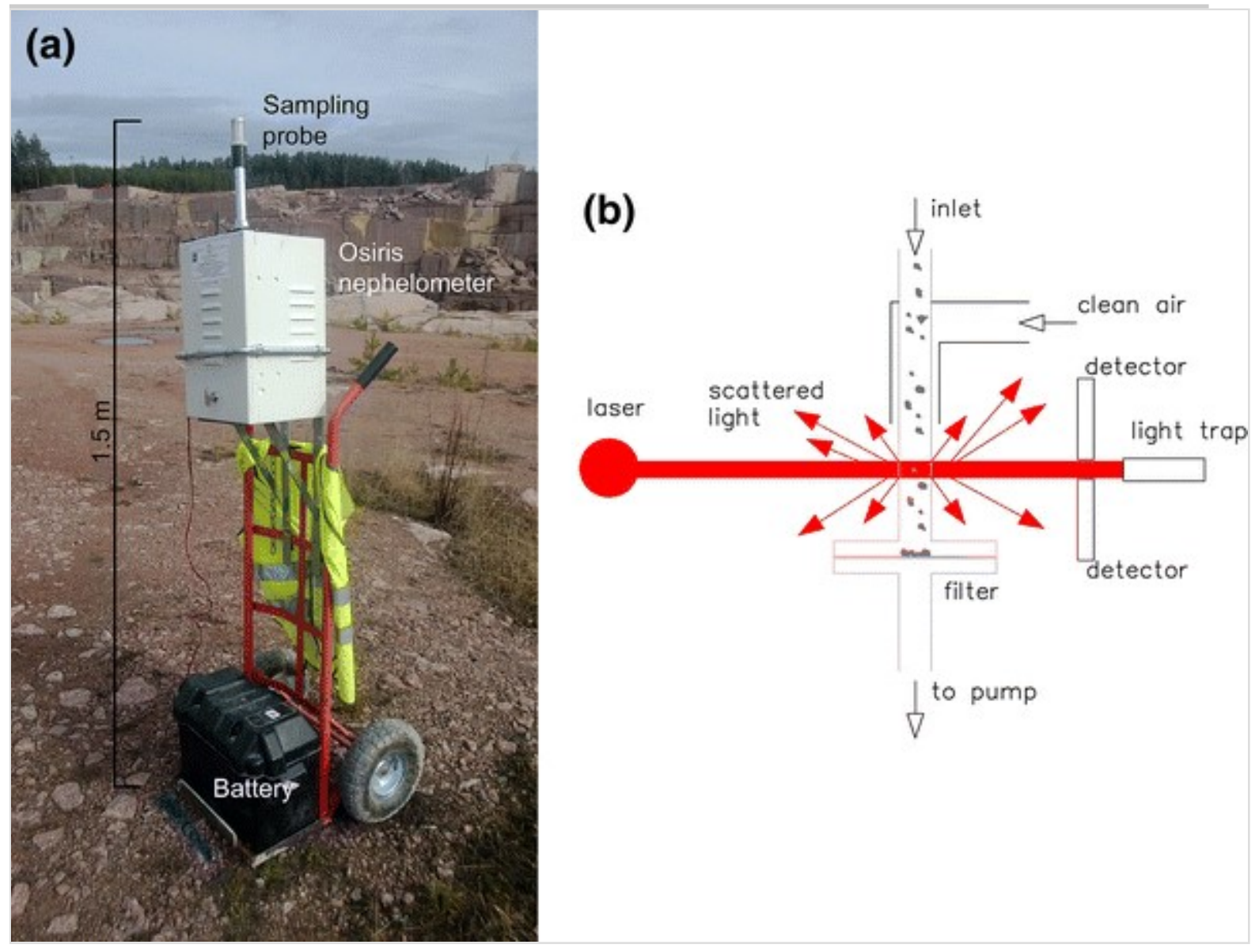

Nephelometer measures four different size categories at the same time: TSP, $\mathrm{PM}_{10}, \mathrm{PM}_{2.5}$, and $\mathrm{PM}_{1}$. The maximum concentration when measuring four different size categories at the same time is approximately $6000 \mu \mathrm{g} / \mathrm{m}^{3}$, whereas restricting measurement to TSP enables measuring concentration up to $60 \mathrm{mg} / \mathrm{m}^{3}$ (Turnkey Instruments Ltd 2009). The Turnkey Osiris nephelometer is standardized for $\mathrm{PM}_{10}$ fraction (Turnkey Instruments Ltd 2014). 
A sampling interval of $5 \mathrm{~s}$ was used in order to observe short time variation in dust emissions. Sampling during the drilling was conducted $3 \times 5$ min periods at each sampling point and 180 measurement results for each size fraction measured, were gained from each sampling point. Occasionally, the sampling duration differed from the planned $15 \mathrm{~min}$ in total due to the demands of the quarrying processes, such as hauling or when the drilling procedure was completed. There were almost 6000 and 10,500 measurement results in total from quarries A and B, respectively, taken into account in this study.

The sampling during the production was manned. Measurements were conducted at two subsequent days and the background concentration measurements during the night between them. Background concentration measurements were unmanned and sampling interval was $300 \mathrm{~s}$. Longer sampling interval for background concentration measurements was chosen because concentration variation was assumed lower during the night time (Turnkey Instruments Ltd 2009).

\section{Measurement setup}

Dust mass concentrations were measured near the drills at different distances at downwind (DW), upwind (UW), and side-wind (SW) direction (see Fig. 3 ). The measurements were conducted at the same elevation as was the drill. The nearest sampling location $5 \mathrm{~m}$ at DW direction remained constant during the measurement. The other sampler was relocated to different distances at different wind directions (Figs. 1b, 3). The sampling height was $1.5 \mathrm{~m}$ which represents breathing height (Fig. $2 \mathrm{a}$ ).

\section{Fig. 3}

Schematic presentation of measurement setup from the lateral point of view. $D W$ downwind, $U W$ upwind, $S W$ side-wind 


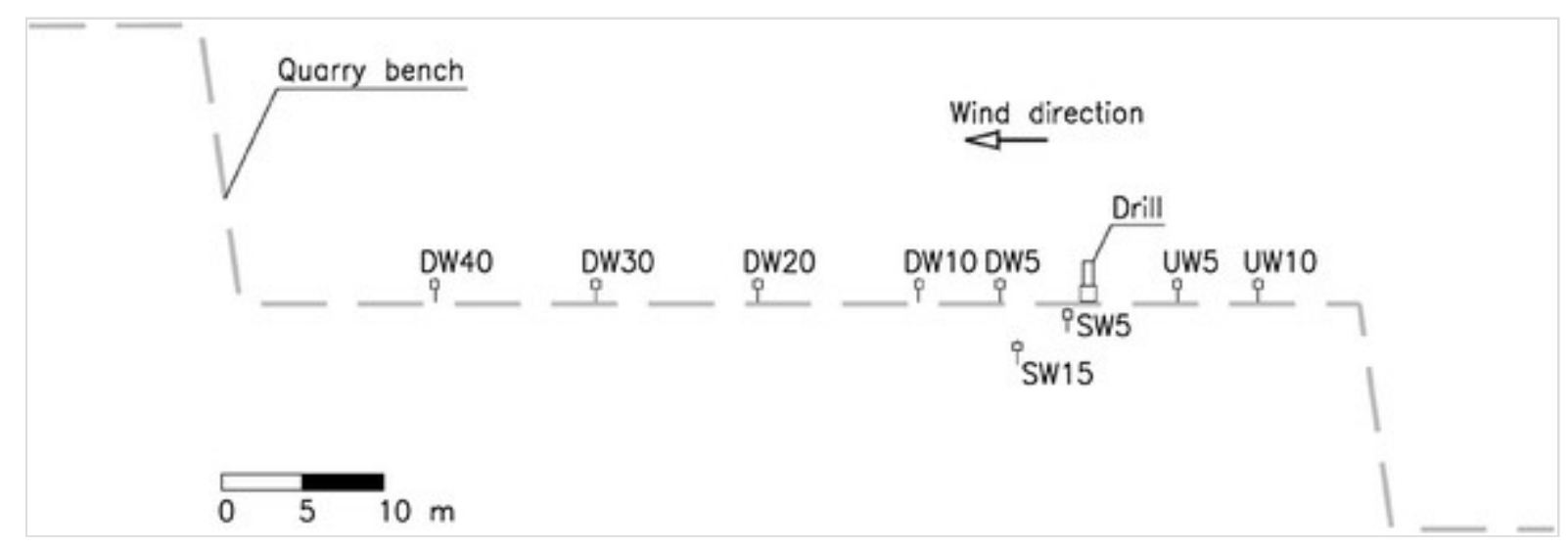

The directions and distances of samples varied between quarries and drills measured due to the drilling location properties and the production in the quarry. Quarry benches prevented measurements usually at one direction. The haul roads inside the quarry also restricted the sampling locations. Because of the high mobility in drilling the distance from drilled hole and dust sampler varied during the measurements. The accuracy of the distances was $\pm 1 \mathrm{~m}$. The lowest variation in distances was when measuring horizontal drilling, due to longer drill holes. The dust samplers were relocated (if possible) when the drilling location shifted. Otherwise, the altering distances were reported in the measurement log sheet.

The background concentrations were measured to control the effect of nearby sources and long distance dust concentrations. The background concentrations were measured inside the quarry near the production measurement site (within few tens of meters) during the night time. The ability to measure background concentration outside the quarry was limited because of the prevailing conditions and safety issues.

\section{Weather conditions}

The measurements were conducted during the winter because the applicability of dust prevention techniques is restricted due to freezing water. Dusting during the winter months is the largest due to the low moisture content and ventilation of the air. There was snow on the ground and temperature was below or near $0{ }^{\circ} \mathrm{C}$. The snow cover on the ground minimized the effect of the dust emission from the quarry surface. This situation represents the maximum dust emission from production. 
The prevailing weather conditions were observed with EasyWeather weather station, which consisted of weather station and recording device (Velleman 2009). The recording device is instructed to be placed indoors. The distance between weather station and recording device is relatively short, not more than approximately $90 \mathrm{~m}$, thus indoor circumstances were unavailable in this study. The winter temperatures caused occasionally interruption in weather monitoring. This was not crucial for the experiment because the duration of production measurement was few hours and the weather conditions stayed relatively stable during the measurements.

The most important weather parameter concerning the scope of this research was the wind direction, which was observed straight from the weather station probe. The weather station monitored temperature, humidity, absolute and relative pressure, wind speed and direction, wind gust speed, and rainfall (Velleman 2009). The average weather conditions were ensured with data gathered from national weather stations located near the quarries $\mathrm{A}$ and $\mathrm{B}$. The weather parameters describing average climatic conditions during the measurement are temperature, relative humidity, and wind speed (Table 3 ).

\section{Table 3}

Weather conditions during measurements

\begin{tabular}{|l|l|l|}
\hline Weather parameter & Quarry A & Quarry B \\
\hline Average temperature $\left({ }^{\circ} \mathrm{C}\right)$ & $-4.2(-5.5$ to -3.4$)$ & $3.6(1.6-5.8)$ \\
\hline Relative humidity $(\%)$ & $91(75$ to 96$)$ & $75(66-87)$ \\
\hline Wind speed (m/s) & $2.7(1.3$ to 4.4$)$ & $3.5(2.2-5.1)$ \\
\hline Variation is presented in parenthesis & \\
\hline
\end{tabular}

The impact of weather conditions on dust mass concentrations were assessed separately for different drill types in different quarries. In this study the results at $5 \mathrm{~m}$ distance DW direction are assessed because DW5 measurement point (see Fig. 3 ) remained the same during the 
measurements and there were the largest amount of concentration results available.

\section{Results}

The mass concentrations were in general highest at the downwind (DW) measurement points and the lowest measured upwind (UW) from the drill. Dust emissions measured at side-wind (SW) locations were in range between results measured locations for DW and UW (Tables 4, 5). Some incoherent results were obtained due to local dust sources such as hauling. The results are reported separately for each different drill type measured (D1V, D1H, D2V, see Table 2).

\section{Table 4}

Coarse particle (TSP and $\mathrm{PM}_{10}$ ) concentrations $\left(\mu \mathrm{g} / \mathrm{m}^{3}\right)$ in two natural stone quarries

\begin{tabular}{|c|c|c|c|c|}
\hline \multirow{3}{*}{$\begin{array}{l}\text { Wind direction/distance } \\
\text { (m) }\end{array}$} & \multicolumn{2}{|l|}{ Quarry A } & \multicolumn{2}{|l|}{ Quarry B } \\
\hline & D1V $\mathrm{a}^{\mathrm{a}}$ & D2 $V^{b}$ & D1 $V^{a}$ & $\mathbf{D} 1 \mathrm{H}^{\mathrm{c}}$ \\
\hline & $\mathrm{TSP} / \mathbf{P M}_{10}$ & $\mathrm{TSP} / \mathbf{P M}_{10}$ & $\mathbf{T S P} / \mathbf{P M}_{10}$ & $\mathbf{T S P} / \mathbf{P M}_{10}$ \\
\hline $\mathrm{DW} / 5$ & $\geq 477 / \geq 355$ & $\geq 916 / \geq 763$ & $31 / 22$ & $\geq 487 / \geq 355$ \\
\hline DW/10 & $258 / 161$ & $180 / 114$ & $17 / 12$ & $\geq 153 / \geq 112$ \\
\hline $\mathrm{DW} / 20$ & $106 / 71$ & $\geq 561 / \geq 463$ & $9 / 7$ & $97 / 61$ \\
\hline $\mathrm{DW} / 30$ & $61 / 41$ & $80 / 47$ & - & $33 / 23$ \\
\hline DW/40 & $81 / 48$ & - & - & $39 / 25$ \\
\hline $\mathrm{DW} / 50$ & $42 / 29$ & - & - & $56 / 35$ \\
\hline DW/60 & - & - & - & $57 / 35$ \\
\hline $\mathrm{UW} / 5$ & $620 / 492$ & - & $15 / 10$ & - \\
\hline \multicolumn{5}{|c|}{$\geq:$ Results include measurements exceeding the measurement capacity } \\
\hline \multicolumn{5}{|c|}{$D W$ downwind, $U W$ upwind, $S W$ side-wind } \\
\hline \multicolumn{5}{|c|}{${ }^{\mathrm{a}} \mathrm{D} 1 \mathrm{~V}=$ drill type 1 , vertical drilling, capacity $0.14 \mathrm{~m} / \mathrm{s}$} \\
\hline \multicolumn{5}{|c|}{${ }^{\mathrm{b}} \mathrm{D} 2 \mathrm{~V}=$ drill type 2 , vertical drilling, capacity $0.22 \mathrm{~m} / \mathrm{s}$} \\
\hline \multicolumn{5}{|c|}{${ }^{\mathrm{c}} \mathrm{D} 1 \mathrm{H}=$ drill type 1 , horizontal drilling, capacity $0.14 \mathrm{~m} / \mathrm{s}$} \\
\hline
\end{tabular}




\begin{tabular}{|c|c|c|c|c|}
\hline \multirow{3}{*}{$\begin{array}{l}\text { Wind direction/distance } \\
\text { (m) }\end{array}$} & \multicolumn{2}{|l|}{ Quarry A } & \multicolumn{2}{|l|}{ Quarry B } \\
\hline & D1V & D2 $V^{b}$ & $\mathrm{D} 1 \mathrm{~V}^{\mathrm{a}}$ & D1 $H^{c}$ \\
\hline & $\mathbf{T S P} / \mathbf{P M}_{10}$ & $\mathrm{TSP} / \mathbf{P M}_{10}$ & $\mathrm{TSP} / \mathbf{P M}_{10}$ & $\mathrm{TSP} / \mathbf{P M}_{10}$ \\
\hline UW/10 & - & $9 / 7$ & $4 / 4$ & - \\
\hline $\mathrm{UW} / 20$ & - & - & $49 / 34$ & - \\
\hline UW/40 & - & $22 / 9$ & - & - \\
\hline $\mathrm{UW} / 50$ & $11 / 9$ & - & - & - \\
\hline $\mathrm{SW} / 5$ & $221 / 133$ & - & - & - \\
\hline $\mathrm{SW} / 10$ & - & $57 / 40$ & - & $371 / 277$ \\
\hline $\mathrm{SW} / 35$ & - & $14 / 10$ & - & - \\
\hline $\mathrm{SW} / 50$ & $34 / 23$ & - & - & - \\
\hline \multicolumn{5}{|c|}{$\geq:$ Results include measurements exceeding the measurement capacity } \\
\hline \multicolumn{5}{|c|}{$D W$ downwind, $U W$ upwind, $S W$ side-wind } \\
\hline \multicolumn{5}{|c|}{${ }^{\mathrm{a}} \mathrm{D} 1 \mathrm{~V}=$ drill type 1 , vertical drilling, capacity $0.14 \mathrm{~m} / \mathrm{s}$} \\
\hline \multicolumn{5}{|c|}{${ }^{\mathrm{b}} \mathrm{D} 2 \mathrm{~V}=$ drill type 2 , vertical drilling, capacity $0.22 \mathrm{~m} / \mathrm{s}$} \\
\hline${ }^{\mathrm{c}} \mathrm{D} 1 \mathrm{H}=$ drill type $1, \mathrm{~h}$ & $1 \mathrm{dri}$ & 0.12 & & \\
\hline
\end{tabular}

\section{Table 5}

Fine particle $\left(\mathrm{PM}_{2.5}\right.$ and $\left.\mathrm{PM}_{1}\right)$ concentrations $\left(\mu \mathrm{g} / \mathrm{m}^{3}\right)$ in two natural stone quarries 


\begin{tabular}{|c|c|c|c|c|}
\hline \multirow{3}{*}{$\begin{array}{l}\text { Wind } \\
\text { direction/distance (m) }\end{array}$} & \multicolumn{2}{|l|}{ Quarry A } & \multicolumn{2}{|l|}{ Quarry B } \\
\hline & D1 $V^{a}$ & D2 $V^{b}$ & D1V ${ }^{a}$ & D1H ${ }^{c}$ \\
\hline & $\mathbf{P M}_{2.5} / \mathbf{P M}_{1}$ & $\mathbf{P M}_{2.5} / \mathbf{P M}_{1}$ & $\mathbf{P M}_{2.5} / \mathbf{P M}_{1}$ & $\mathbf{P M}_{2.5} / \mathbf{P M}_{1}$ \\
\hline $\mathrm{DW} / 5$ & $\geq 32.6 / \geq 10.4$ & $\geq 61.9 / \geq 28.7$ & $3.5 / 0.7$ & $\geq 34.2 / \geq 7.7$ \\
\hline $\mathrm{DW} / 10$ & $28.1 / 6.2$ & $16.3 / 4.1$ & $3.4 / 0.6$ & $13.4 / 2.5$ \\
\hline $\mathrm{DW} / 20$ & $14.3 / 4.5$ & $52.7 / 27.4$ & $2.6 / 0.5$ & $12.7 / 2.1$ \\
\hline $\mathrm{DW} / 30$ & $9.1 / 3.4$ & $10.4 / 3.1$ & - & $6.2 / 1.2$ \\
\hline $\mathrm{DW} / 40$ & $14.5 / 4.7$ & - & - & $6.9 / 1.3$ \\
\hline $\mathrm{DW} / 50$ & $7.9 / 3.3$ & - & - & $8.3 / 1.4$ \\
\hline $\mathrm{DW} / 60$ & - & - & - & $8.8 / 1.6$ \\
\hline $\mathrm{UW} / 5$ & $32.9 / 9.9$ & - & $3.2 / 0.6$ & - \\
\hline $\mathrm{UW} / 10$ & - & $4.4 / 2.2$ & $1.9 / 0.4$ & - \\
\hline $\mathrm{UW} / 20$ & - & - & $6.7 / 1.1$ & - \\
\hline $\mathrm{UW} / 40$ & - & $3.9 / 1.9$ & - & - \\
\hline $\mathrm{UW} / 50$ & $5.6 / 3.0$ & - & - & - \\
\hline $\mathrm{SW} / 5$ & $25.2 / 6.1$ & - & - & - \\
\hline $\mathrm{SW} / 10$ & - & $19.1 / 6.5$ & - & $31.7 / 7.4$ \\
\hline $\mathrm{SW} / 35$ & - & $5.8 / 2.6$ & - & - \\
\hline $\mathrm{SW} / 50$ & $6.9 / 3.3$ & - & - & - \\
\hline \multicolumn{5}{|c|}{$\geq:$ Results include measurements exceeding the measurement capacity } \\
\hline \multicolumn{5}{|c|}{$D W$ downwind, $U W$ upwind, $S W$ side-wind } \\
\hline \multicolumn{5}{|c|}{${ }^{\mathrm{a}} \mathrm{D} 1 \mathrm{~V}=$ Drill type 1 , vertical drilling, capacity $0.14 \mathrm{~m} / \mathrm{s}$} \\
\hline \multicolumn{5}{|c|}{${ }^{\mathrm{b}} \mathrm{D} 2 \mathrm{~V}=$ Drill type 2 , vertical drilling, capacity $0.22 \mathrm{~m} / \mathrm{s}$} \\
\hline \multicolumn{5}{|c|}{${ }^{\mathrm{c}} \mathrm{D} 1 \mathrm{H}=$ Drill type 1 , horizontal drilling, capacity $0.14 \mathrm{~m} / \mathrm{s}$} \\
\hline
\end{tabular}

The highest results exceeded the measuring capacity of the nephelometer, when measuring near the drill (5-20 m distance) at DW direction. High 
results for fine particles beyond $5 \mathrm{~m}$ were only singular anomalies counting under $0.5 \%$ of results. At $5 \mathrm{~m}$ DW direction results exceeding the measuring capacity were for both drill D1V in quarry A and drill D1H in quarry B approximately $1 \%$, whereas drill D2V in quarry A gained approximately $4 \%$ results exceeding measurement capacity. It seemed that high dust emission was produced particularly when the drilling started and ended and when pulling the drill rod out from the drill hole.

\section{Coarse particles: TSP and $\mathrm{PM}_{10}$}

For the coarse particles the results were similar for TSP and $\mathrm{PM}_{10}$ in both quarries. The mass concentration decreases rapidly with increasing distance (Fig. 4) at all wind directions. Decrease was more distinct for TSP compared to $\mathrm{PM}_{10}$ and the most pronounced at the upwind direction (Table 4). TSP concentration was roughly 1.5 times higher than $\mathrm{PM}_{10}$ concentration.

\section{Fig. 4}

The $\mathrm{PM}_{10}$ concentrations produced during horizontal drilling at 5 and $10 \mathrm{~m}$ distances at downwind in quarry B

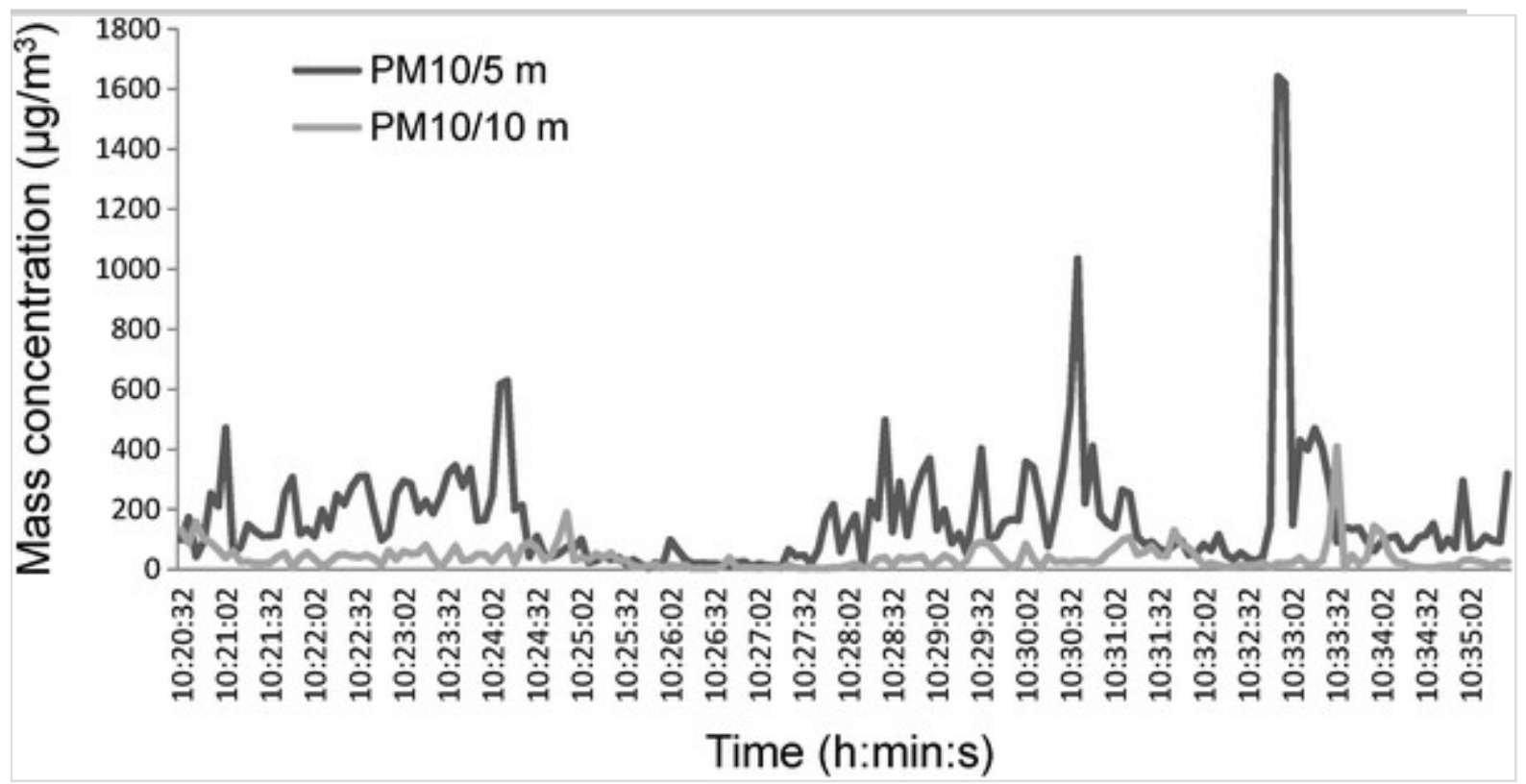


Local dust sources like hydraulic splitting, dust handling and hauling affects the results inside the quarry, resulting higher concentrations than measured close to the dust source (Table 4). Higher concentrations than expected were observed $40 \mathrm{~m}$ DW in quarry A and $20 \mathrm{~m} \mathrm{UW}$ in quarry B. In both cases sampling locations had other potential dust sources nearby.

Typical mass concentration variation during the measurements with short (seconds) sampling interval was significant, varying from 1 to over $6000 \mu \mathrm{g} / \mathrm{m}^{3}$. The mass concentration measured was quite low in general, but the concentration peaks were high compared to the median level (Fig. 4), which is also supported by statistical analysis. Median mass concentrations were significantly lower compared to average mass concentrations. The average concentrations were approximately $2-5$ times higher than the median concentration for coarse particles. To avoid underestimation of dust caused by the quarrying, the average mass concentration was assumed to be more representative compared to the median values. The concentration variances were $3-23$ and $4-32 \%$ for TSP and $\mathrm{PM}_{10}$, respectively.

DW concentration peaks observed at $5 \mathrm{~m}$ distance were also observed later at longer distances (for example 5 and $10 \mathrm{~m}$ distance from the drill, see Fig. 4). Concentration peaks descend with increasing distance and at $50 \mathrm{~m}$ distance the concentration peaks were only barely distinguished from the altering median level.

Background concentrations in quarries A and B were 11 and $11 \mu \mathrm{g} / \mathrm{m}^{3}$ for TSP and 9 and $8 \mu \mathrm{g} / \mathrm{m}^{3}$ for $\mathrm{PM}_{10}$, respectively.

\section{Fine particles: $\mathrm{PM}_{2.5}$ and $\mathrm{PM}_{1}$}

Apart from the downwind direction near the drill the fine particle mass concentrations were low for $\mathrm{PM}_{2.5}$ and for $\mathrm{PM}_{1}$. The effect of local dust sources (hydraulic splitting, dust handling, and hauling) were also observed for fine particles. The effect was more evident for $\mathrm{PM}_{2.5}$ than for $\mathrm{PM}_{1}$. Fine particles mass concentrations decreased also with increasing 
distance (Fig. 5) at all wind directions and the decreasing was more pronounced for $\mathrm{PM}_{2.5}$ and at $\mathrm{UW}$ direction (Table 5). $\mathrm{PM}_{2.5}$ concentration was roughly $25 \%$ of $\mathrm{PM}_{10}$ concentration and $\mathrm{PM}_{1}$ was under $10 \%$ of $\mathrm{PM}_{10}$ concentration.

Fig. 5

The $\mathrm{PM}_{2.5}$ concentrations produced during horizontal drilling at 5 and $10 \mathrm{~m}$ distances at downwind in quarry B

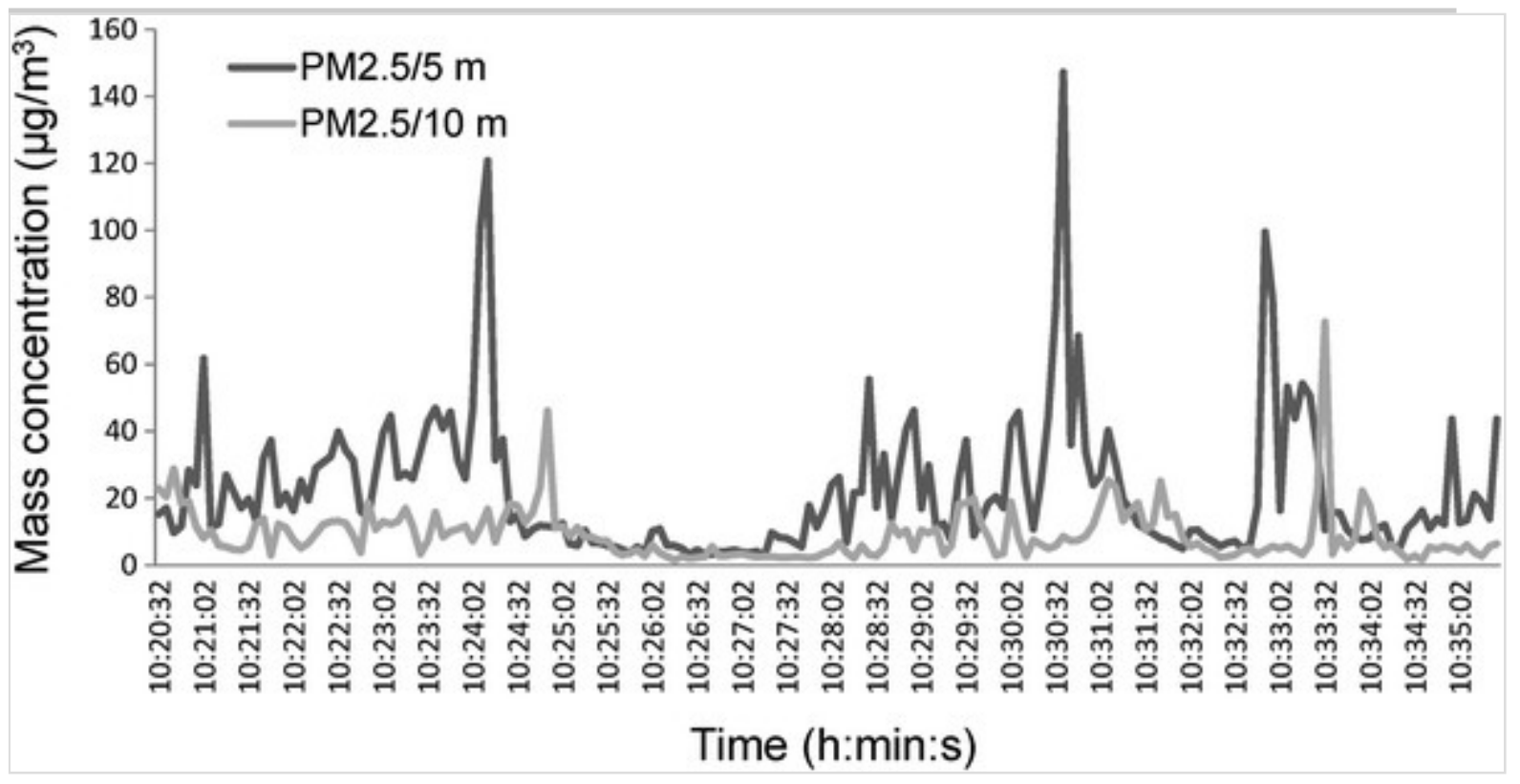

Typical mass concentration variation was significant, varying from between 1 to more than $650 \mu \mathrm{g} / \mathrm{m}^{3}$. The mass concentration measured was quite low in general, mainly under $25 \mu \mathrm{g} / \mathrm{m}^{3}$, but the concentration peaks were high compared to the median level (Fig. 5). The variation was similar to the variation of coarse particles, especially for $\mathrm{PM}_{2.5}$. Average concentrations were approximately 1-2 times median concentration for fine particles. The concentration variances were $1-19$ and $1-35 \%$ for $\mathrm{PM}_{2.5}$ and $\mathrm{PM}_{1}$, respectively.

DW concentration peaks observed at $5 \mathrm{~m}$ distance were observed slightly later at longer distances and concentration peaks descend with increasing distance also for fine particles (Fig. 5) as did coarse particles. At $50 \mathrm{~m}$ 
distance the fine particles concentration peaks were also only barely distinguished from the median level.

Background concentrations in quarries A and B were 5.5 and $2.6 \mu \mathrm{g} / \mathrm{m}^{3}$ for $\mathrm{PM}_{2.5}$ and 2.8 and $0.4 \mu \mathrm{g} / \mathrm{m}^{3}$ for $\mathrm{PM}_{1}$, respectively.

\section{Mass concentrations during varying weather conditions}

All considered weather parameters (temperature, relative humidity, and wind speed) showed unsystematic effect on the mass concentration results. Results were similar for all size categories. As an example, $\mathrm{PM}_{10}$ concentrations at $5 \mathrm{~m} \mathrm{DW}$ are described more detailed below.

Temperature remained relatively constant, within $\pm 5^{\circ} \mathrm{C}$, during the measurements and it was below $0{ }^{\circ} \mathrm{C}$ and above it during the measurements in quarry A and quarry B, respectively. Despite the temperature changes, $\mathrm{PM}_{10}$ concentration stayed approximately at $470 \mu \mathrm{g} / \mathrm{m}^{3}$ in quarry A. In quarry B $\mathrm{PM}_{10}$ concentration rose from approximately $380-620 \mu \mathrm{g} / \mathrm{m}^{3}$, when temperature rose from $1.6-2.1$ to 3.7 $-5{ }^{\circ} \mathrm{C}$.

Also, the relative humidity showed no effect when measuring drill D1V in quarry A. Instead $\mathrm{PM}_{10}$ concentration produced by drill $\mathrm{D} 2 \mathrm{~V}$ doubled from $600 \mu \mathrm{g} / \mathrm{m}^{3}$ to over $1200 \mu \mathrm{g} / \mathrm{m}^{3}$, when relative humidity raised form $>70-80$ to $>90 \%$. However, in quarry B the increase in relative humidity from $>70$ -80 to $>80-90 \%$ decreased $\mathrm{PM}_{10}$ concentration from 580 to $290 \mu \mathrm{g} / \mathrm{m}^{3}$, respectively.

Decreasing concentration with increasing wind speed was observed when measuring D1V in quarry A and D1H in quarry B. D2 V in quarry A had concentration relatively constant with all wind speeds observed during the measurements (Fig. 6).

\section{Fig. 6}

$\mathrm{PM}_{10}$ concentrations at $5 \mathrm{~m}$ distance at downwind direction near different drills with different wins speed 


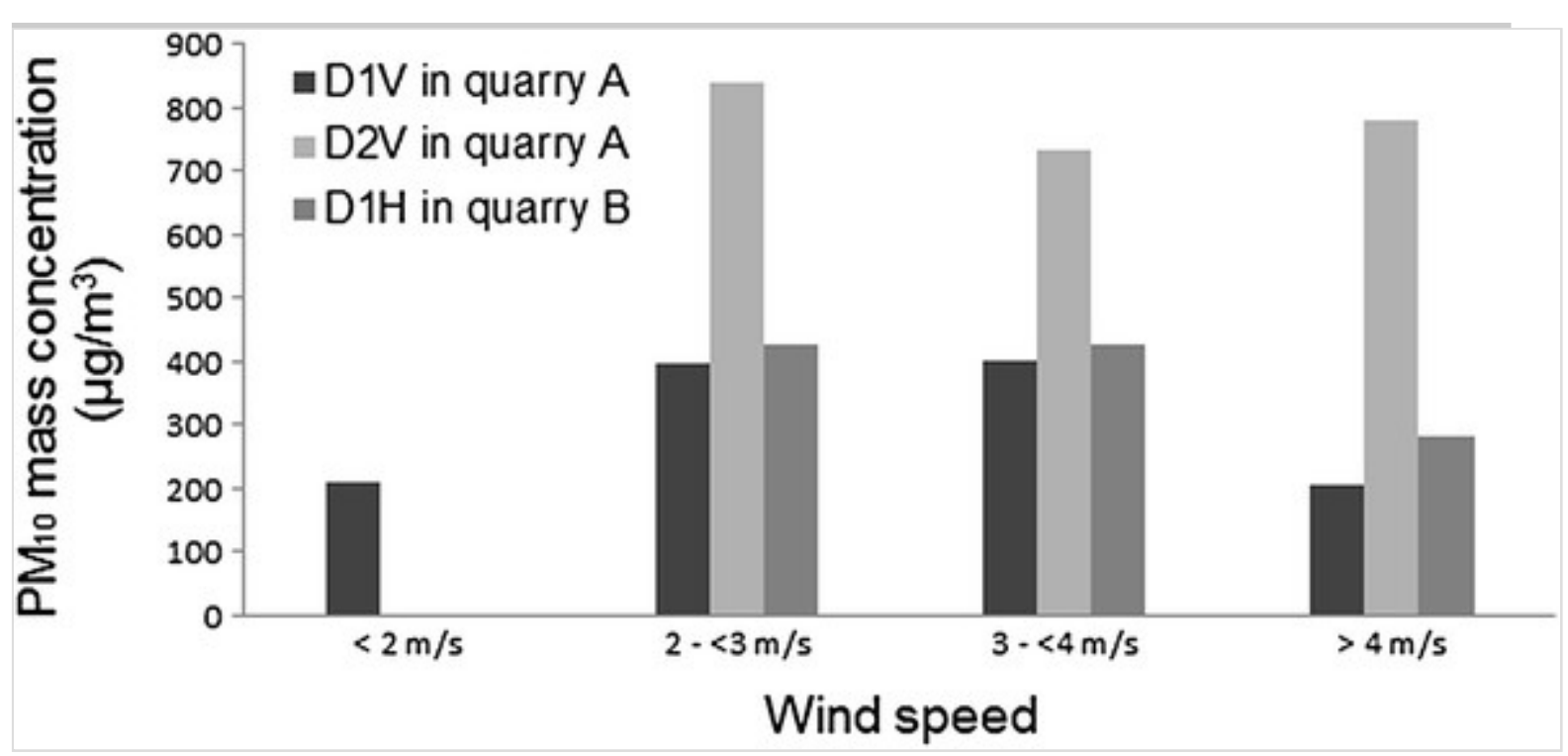

AQ1

\section{The decrease of mass concentration with increasing distance}

Dust mass concentration decrease with increasing distance at DW direction was similar for coarse (TSP and $\left.\mathrm{PM}_{10}\right)$ and fine particles $\left(\mathrm{PM}_{2.5}\right.$ and $\left.\mathrm{PM}_{1}\right)$ (see Tables 4, 5). Therefore, the decrease for $\mathrm{PM}_{10}$ and $\mathrm{PM}_{2.5}$ represent coarse and fine particles, respectively (Figs. 7, 8).

Fig. 7

$\mathrm{PM}_{10}$ concentration at downwind direction in different quarries $\mathrm{A}$ and $\mathrm{B}$ near different drill types D1H, D1V, and D2V 


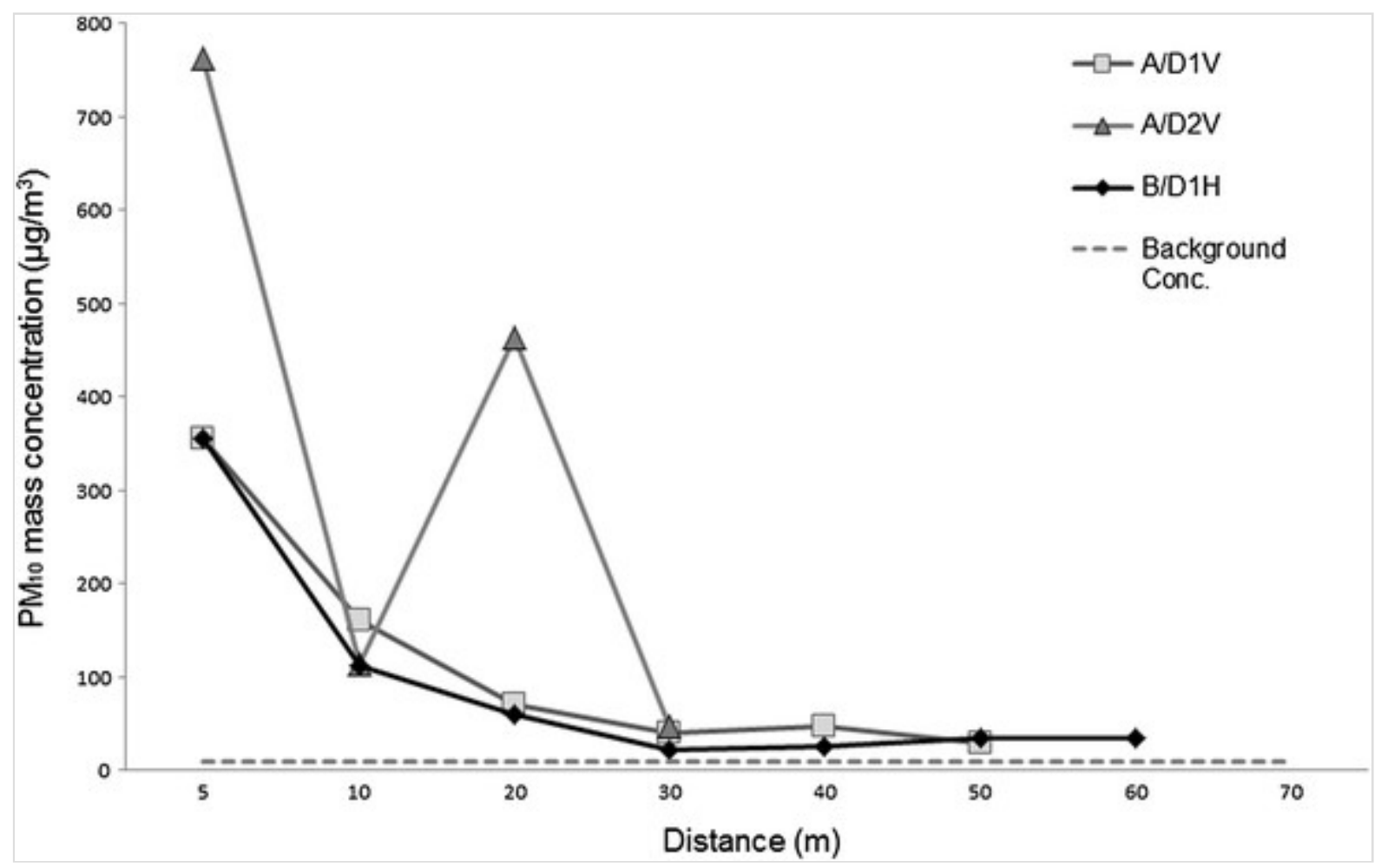

Fig. 8

$\mathrm{PM}_{2.5}$ concentration at downwind direction in different quarries $\mathrm{A}$ and $\mathrm{B}$ near different drill types D1H, D1V and D2V

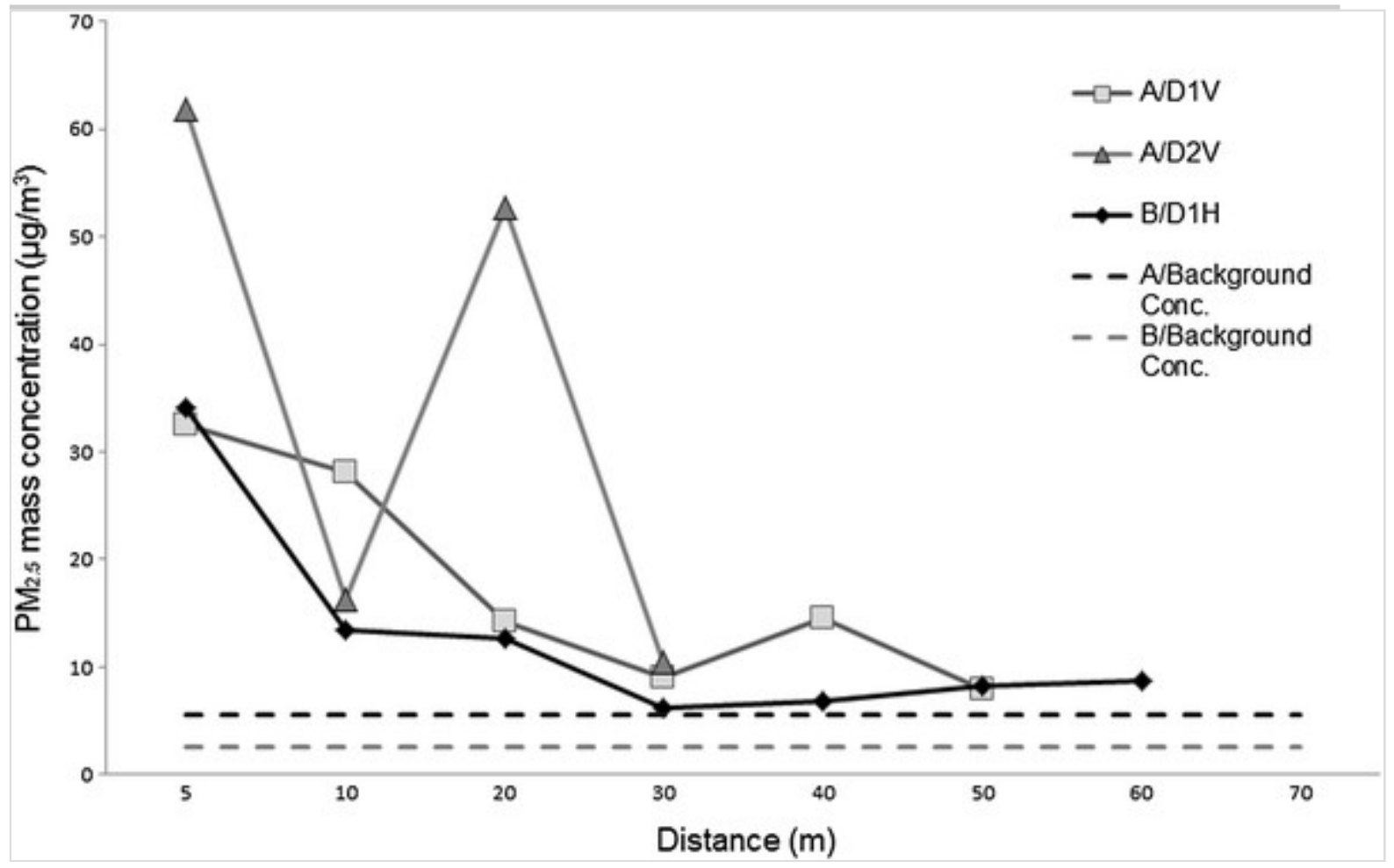


Drilling capacity had an effect on dust mass concentration near (at $5 \mathrm{~m}$ distance) the drill. The drill D2V with higher $(0.22 \mathrm{~m} / \mathrm{s})$ drilling capacity gained higher dust mass concentration, approximately $760 \mu \mathrm{g} \mathrm{PM}_{10} / \mathrm{m}^{3}$, at $5 \mathrm{~m}$ distance DW compared to drills D1V and D1H with lower $(0.14 \mathrm{~m} / \mathrm{s})$ drilling capacity, both approximately $360 \mu \mathrm{g} \mathrm{PM} 10 / \mathrm{m}^{3}$ (see Table 4 ). The difference with dust mass concentrations was vanished already at $10 \mathrm{~m}$ distance, where concentrations were same order of magnitude, roughly $100 \mu \mathrm{g} \mathrm{PM}_{10} / \mathrm{m}^{3}$.

The decrease of mass concentration with increasing distance was evaluated for determining the distance where the background concentrations were achieved. Results from drill D1H in quarry B and drill D1V in quarry A were selected for further analysis, because both drills gained results from several different sampling locations downwind and variation of results was only modest (approximately 10\%). Drills D2V from quarry A and D1V from quarry B were excluded from further analysis due to higher variation (approximately 20\%) and low dust mass concentration (10 times lower compared to other drills), respectively. Higher variation in D2V results was affected by other dust sources. The low concentration level measured near D1V in quarry B was possibly because of sampling dislocation in relation to wind direction and results were excluded to avoid underestimation. Results for horizontal and vertical drilling are addressed separately in the "Horizontal drilling" and "Vertical drilling".

The decreasing of dust mass concentration with increasing distance was assessed for DW direction in which the decreasing was the slowest compared to the SW and UW directions. The exponential equation curves for dust retention were determined via the best fitting curve to the measured concentrations of different size categories by Excel.

\section{Horizontal drilling}

The horizontal drilling with D1H occurred in isolated location at the upwind direction compared to other production activities operating during the measurements in the quarry B. Therefore, the results of horizontal 
drilling were consistent and the inaccuracy of measuring distances were the lowest.

The equations derived for mass concentration retention of coarse particles:

$$
\begin{gathered}
C_{\mathrm{TSP}}=235.9 \times \mathrm{e}^{-0.034 x} \\
C_{\mathrm{PM} 10}=172.0 \times \mathrm{e}^{-0.037 x},
\end{gathered}
$$

where $C_{\mathrm{TSP}}$ is mass concentration of TSP, $C_{\mathrm{PM} 10}$ is mass concentration of $\mathrm{PM}_{10}$ and $\mathrm{x}$ is the distance from the drill in meters. According to these equations, the background concentration for TSP and $\mathrm{PM}_{10}$ is achieved at distances 90 and $83 \mathrm{~m}$, respectively.

The equations derived for mass concentration retention of fine particles:

$$
\begin{aligned}
& C_{\mathrm{PM} 2.5}=20.18 \times \mathrm{e}^{-0.02 x} \\
& C_{\mathrm{PM} 1}=3.99 \times \mathrm{e}^{-0.022 x},
\end{aligned}
$$

where $C_{\mathrm{PM} 2.5}$ is mass concentration of $\mathrm{PM}_{2.5}, C_{\mathrm{PM} 1}$ is mass concentration of $\mathrm{PM}_{1}$ and $x$ is the distance from the drill in meters. The distances where the background concentration are achieved Based on the equations, the background concentration for $\mathrm{PM}_{2.5}$ and $\mathrm{PM}_{1}$ is achieved at distances 102 and $105 \mathrm{~m}$, respectively.

\section{Vertical drilling}

The vertical drilling with D1V in quarry A had consistent results and variation was same level as was for the horizontal drilling. The concentration results were in the same order of magnitude compared to other drill types examined.

The equations derived for mass concentration retention of coarse particles:

$$
C_{\mathrm{TSP}}=414.3 \times \mathrm{e}^{-0.049 x}
$$




$$
C_{\mathrm{PM} 10}=284.8 \times \mathrm{e}^{-0.05 x},
$$

where $C_{\mathrm{TSP}}$ is mass concentration of TSP, $C_{\mathrm{PM} 10}$ is mass concentration of $\mathrm{PM}_{10}$ and $x$ is the distance from the drill in meters. According to these equations, the background concentration for TSP and $\mathrm{PM}_{10}$ is achieved at distances 74 and $69 \mathrm{~m}$, respectively.

The equations derived for mass concentration retention of fine particles:

$$
\begin{gathered}
C_{\mathrm{PM} 2.5}=32.58 \times \mathrm{e}^{-0.029 x} \\
C_{\mathrm{PM} 1}=8.38 \times \mathrm{e}^{-0.02 x},
\end{gathered}
$$

where $C_{\mathrm{PM} 2.5}$ is mass concentration of $\mathrm{PM}_{2.5}, C_{\mathrm{PM} 1}$ is mass concentration of $\mathrm{PM}_{1}$ and $x$ is the distance from the drill in meters. Based on the equations, the background concentration for $\mathrm{PM}_{2.5}$ and $\mathrm{PM}_{1}$ is achieved at distances 61 and $55 \mathrm{~m}$, respectively.

\section{Discussion}

\section{Dust mass concentration levels}

The majority of dust formed during the quarrying consists on coarse particles (TSP and $\mathrm{PM}_{10}$ ). Results are in accordance with previous observations (e.g. Office of the Deputy Prime Minister 2003; Cattle et al. 2012). The fine particle mass emissions were low especially for $\mathrm{PM}_{1}$, which was mainly under $10 \mu \mathrm{g} / \mathrm{m}^{3}$. This implies that fine particles originate largely from other, remote sources and from machinery used in the quarry. Also, the statistical analysis supports this. Coarse particles has the average concentrations $2-5$ times higher than the median concentrations, whereas fine particles gain the average concentrations only 1-2 times higher than the median concentrations. High concentration peaks from the production caused higher average concentrations compared to median concentrations of coarse particles. 
TSP concentrations measured near the source $(5 \mathrm{~m})$ were approximately at the same level (few hundreds of micrograms per cubic meter) as were reported for controlled drills by Organiscak and Page (1995). They observed significant dust retention within few tens of meters, which was perceived also in this study. Bada et al. (2013) reports mass concentration in the same order of magnitude for TSP and $\mathrm{PM}_{2.5}$ as measured in this study. Degan et al. (2013), Junttila et al. (1996) and Olusegun et al. (2009) measured approximately ten or more times higher and Golbabaei et al. (2004) approximately 100-200 times higher concentrations compared to this study. Instead Aatos (2003) measured lower concentrations compared to results in this study. Results reported by Aatos (2003) were affected by long sampling distance $(50 \mathrm{~m})$. The results in Junttila et al. (1996) and Olusegun et al. (2009) were influenced by other quarrying activities, e.g. crushing. The difference compared to the high concentrations gained by Golbabaei et al. (z0132004) The correct year of reference Golbabaei et al. is 2004. Year 2013 is a typo. may have had an influence of the measurement setup.

AQ2

The wind direction had a crucial impact on dust mass concentrations and spreading. The concentrations were much lower in the UW and SW direction compared to DW direction, which was expected. Some incoherent results appeared due to other dust sources. Concentrations higher than expected were observed at $40 \mathrm{~m}$ DW in quarry A and $20 \mathrm{~m}$ UW in quarry B. Incoherent results were measured near hauling (quarry A) and dust handling (quarry B). The high mass concentration at the nearest $(5 \mathrm{~m})$ measurement location UW direction (D1V in quarry A) is assumed to be consequence of drilling imparting a momentum to the dust enabling it to overcome the wind, which was also observed by Reed (2003) during haul road dust measurements.

Drilling capacity had an impact on dust mass concentration near (at $5 \mathrm{~m}$ distance DW) the drill. The higher drilling capacity equipment (D2V) produced larger amount of dust. Concentration differences vanished quickly with increasing distance and at $10 \mathrm{~m}$ distance both vertical drills 
$\mathrm{D} 1 \mathrm{~V}$ and D2V had mass concentration in same order of magnitude, roughly $100 \mu \mathrm{g} \mathrm{PM}_{10} / \mathrm{m}^{3}$. This is assumed to be consequence of the large proportion of coarse particles formed during the drilling, which settle near the dust source.

\section{Impact of weather conditions on dust mass concentration}

Weather conditions stayed relatively constant during the measurements. Impacts of weather conditions on results were inconsistent. Temperature had no impact on results when temperature was below $0{ }^{\circ} \mathrm{C}$, but when above it, increasing temperature increased dust mass concentration. Correlation was inconsistent between relative humidity and dust concentration. Increasing relative humidity seemed both to increase and decrease mass concentration, when considering different drill types in different quarries. During high wind speed ( $>4 \mathrm{~m} / \mathrm{s}$ ) low mass concentrations were measured near D1V in quarry A and D1H in quarry B. Wind speed had no effect on concentration results measured near D2V in quarry A.

Longer sampling periods than applied in this study would enable observations of the concentration level during altering weather conditions. Modest variation in weather conditions is the main reason for the incoherent results. The conditions lacked sufficient variation to cause notable differences. In addition, differing weather conditions appeared in different quarries during measurements of different drill types, which increases the variance in results and, therefore, complicates the ability to observe weather conditions impacts. The chosen climatic conditions (winter) and the observed lack of consistency in weather parameters impacts on dust concentrations confirm the reliability of results representing the dust emission from the natural stone production during similar circumstances.

\section{Distance affecting on dust concentration}


Measuring dust mass concentration during the drilling showed that drilling produces mainly coarse dust particles which settle near the dust source. High concentration peaks observed at DW direction were seen both in the nearest sampler $(5 \mathrm{~m})$ and other sampler locations (distance $10 \mathrm{~m}$ or more). When distance was $50 \mathrm{~m}$ or more, the peaks were only barely distinguished from the altering median level. The results reveal the same circumstance which was visible in the quarry area during the measurement: Drilling produces short time dust plumes which travel with a wind and after short period of time dilutes inseparable.

The background concentration of all particle sizes was achieved at 55 $-105 \mathrm{~m}$ distance from the dust source, depending on the drill type and dust size category. The dust retention was more pronounced with larger size categories (TSP and $\mathrm{PM}_{10}$ ) as they settled nearer the dust source compared to the fine particles. The background concentration was attained 69-90 m distance for coarse particles and at 55-105 $\mathrm{m}$ distance for fine particles. Considering the distance where the background concentration is achieved near the natural stone quarries, a generalisation of $100 \mathrm{~m}$ is applicable. This rough approximation avoids underestimation in most of the cases. This means that dust mass concentration measurements evaluating quarries dust load to the environment should be conducted at short distances from the quarry boundary or even inside the quarry. The dust concentration can vary strongly during certain weather conditions, but the dust concentration spread over $100 \mathrm{~m}$ distances from the source is low due to the ventilating effect of the wind.

Background concentration measurements conducted during the night time may have had an impact on the results. At night the dust concentration is lower due to lack of dust sources, like traffic. This may have caused an underestimation on the background concentration. The background concentration measurements during the night are justifiable to gain measurements during similar weather conditions as production measurements. Longer breaks in the production appear usually in the summertime (mainly in July). The impact of weather conditions when comparing winter and summer time is estimated to be greater than the 
impact of background concentration measurement occurring at non-dusty time of the day.

Even though the background concentrations may be underestimated, the background concentrations were reached within 55-105 $\mathrm{m}$ distance. This is on the same order of magnitude as Reed's (2003) results, in which the quarry haul road dust concentration reached background concentration approximately at $30 \mathrm{~m}$ distance. The certainty of the evaluation of distance in which the background concentration is achieved, is increased by the possible underestimation of background concentration. The generalization of $100 \mathrm{~m}$ as a distance where background concentration is achieved is, therefore, applicable concerning dust emission from production for natural stone quarries processing hard rocks.

\section{Conclusions}

The dust mass concentrations produced during drilling in natural stone quarries showed large variations due to the local air currents present inside the quarry and the phase of the drilling procedure. Wind direction had a crucial effect on dust dispersion. Increasing wind speed seemed to decrease the dust concentration. The impact of other considered weather conditions, temperature and relative humidity, on dust concentration were inconsistent.

Drilling produces mainly coarse (TSP and $\mathrm{PM}_{10}$ ) dust particles which settle near the dust source. The fine particle mass concentrations were low, mainly under $25 \mu \mathrm{g} / \mathrm{m}^{3}$, and they originate mainly from other remote sources and from the machinery used in the quarries.

The drilling capacity effected on dust mass concentration near the drill (approximately $5 \mathrm{~m}$ ), but the impact vanished quickly with increasing distance (approximately $10 \mathrm{~m}$ ).

Local dust sources, such as hauling, had a significant impact on dust mass concentrations even inside the quarry. The dust formed in the quarry will 
spread approximately at $100 \mathrm{~m}$ distance from the dust source after which the dust mass concentration achieves the background level.

\section{Acknowledgements}

Palin Granit Oy is acknowledged for access to the quarries. The site personnel is thanked for their support during the measurements. FCG Finnish Consulting Group Oy is acknowledged for the usage of Osiris nephelometers and allowing the usage of the working equipment and space. K. H. Renlund foundation made this research possible with their financial support. Professor Mikael Rinne (Aalto University), as well as two anonymous reviewers are acknowledged for their valuable comments on the paper.

\section{References}

Aatos S (ed) (2003) Environmental effects in natural stone production life cycle (Luonnonkivituotannon elinkaaren aikaiset ympäristövaikutukset). Suomen ympäristö, Luonto ja luonnonvarat 656, Ympäristöministeriö (in Finnish with an English summary)

Bada BS, Olatunde KA, Akande OA (2013) Air quality assessment in the vicinity of quarry site. Environ Nat Resour Res 3(2):111-115

Belardi G, Vignaroli G, Plescia P, Passeri L (2013) The assessment of particulate matter emitted from stone-crushing industry by correlating rock textures with particles generated after comminution and dispersed in air environment. Environ Sci Pollut Res Int 20(7):4711-4728

Cattle SR, Hemi K, Pearson GL, Sanderson T (2012) Distinguishing and characterizing point-source mining dust and diffuse-source dust deposits in a semi-arid district of eastern Australia. Aeolian Res 6:21 $-29$ 
Degan GA, Lippiello D, Pinzari M (2013) Monitoring airborne dust in an Italian basalt quarry: comparison between sampling methods. Air Pollut XXI 174:75-84

EN 12670 (2001) Natural stone. Terminology. European Committee for Standardization. ISBN 058039185 X, pp 49 AQ3

Golbabaei F, Barghi M-A, Sakhaei M (2004) Evaluation of workers' exposure to total, respirable and silica dust and the related health symptoms in Senjedak stone quarry, Iran. Ind Health 42:29-33

Härmä P, Selonen O (2008) Surface weathering of rapakivi granite outcrops - implications for natural stone exploration and quality evaluation. Estonian J Earth Sci 57(3):135-148

Härmä P, Selonen O, Luodes H (2015) The Wiborg granite batholith - the main production area for granite in Finland. In: Lollino $\mathrm{G}$ et al (ed) Engineering geology for society and territory, vol 5, Springer International Publishing, Switzerland, pp 259-262, doi: 10.1007/978-3-319-09048-1

Hedges KJG (2016) Assessment and control of respirable crystalline silica in quarries and dimension stone mines. Thesis, School of Science and Health, Western Sydney University, Sydney

Hinds WC (ed) (1999) Aerosol technology: properties, behavior and measurement of airborne particles, 2 nd edn. Wiley-Interscience, New York, pp 15-53

Junttila S, Tossavainen A, Hartikainen T, Härmä P, Korhonen K, Suominen V, Pyy L (1996) Airborne mineral fibers and quartz dust in precambrian metamorphic limestone and dolomite mines in Finland. Appl Occup Envinron Hyg 11(8):1075-1080 
Junttila S, Tossavainen A, Hartikainen T, Härmä P, Korhonen K, Suominen V, Pyy L (1997) Airborne mineral dust at nine crushed rock plants in Finland. Appl Occup Envinron Hyg 12(12):882-886

Lindberg B, Bergman L (1993) Pre-quaternary rocks of the Vehmaa map-sheet area. Geological Survey of Finland. Geological map of Finland 1:100 000, explanation to the maps of pre-quaternary rocks, Sheet 1042 Vehmaa, Espoo (in Finnish with an English summary)

Madl AK, Donovan EP, Gaffney SH, McKinley MA, Moody EC, Henshaw JL, Paustenbach DJ (2008) State-of-the-science review of the occupational health hazards of crystalline silica in abrasive blasting operations and related requirements for respiratory protection. J Toxicol Environ Health Part B Crit Rev 11(7):548-608

Office of the Deputy Prime Minister (2003) Mineral policy statement 2: controlling and mitigating the environmental effects of minerals extraction in England. MPS2, London, UK

Olusegun O, Adeniyi A, Adeola GT (2009) Impact of granite quarrying on the health of workers and nearby residents in Abeokuta Ogun State, Nigeria. Ethiopian J Environ Stud Manag 2(1):1-11

Organiscak JA, Page SJ (1995) Assessment of airborne dust generated from small truck-mounted rock drills. RI 9616, Report of investigations/1995, United States Department of the Interior, United States Bureau of Mines, Pittsburgh

Organiscak JA, Page SJ (2005) Development of a dust collector inlet hood for enhanced surface mine drill dust capture. Int J Surf Min Reclam Environ 19(1):12-28

Räisänen M (2004) From outcrops to dust-mapping, testing, and quality assessment of aggregates. University of Helsinki, Publications of the Department of Geology D1, Yliopistopaino Helsinki 
Reed WR (2003) An improved model for prediction of PM10 from surface mining operations. Dissertation submitted to the faculty of the Virginia Polytechnic Institute and State University in partial fulfillment of the requirements for the degree of doctor in philosophy in mining and minerals engineering. Blacksburg, Virginia

Romu I (ed) (2014) Best environmental practices (BEP) for natural stone production (Parhaat ympäristökäytännöt (BEP) luonnonkivituotannossa). The Finnish Environment 5/2014 (in Finnish with an English summary)

Sairanen M (2014) Dust emissions in natural stone production (Pölypäästöt luonnonkivituotannossa). In: Romu I (ed) Best environmental practices (BEP) for natural stone production. The Finnish Environment 5/2014, pp 44-60 (in Finnish)

Sairanen M, Rinne M, Selonen O (2017) A review of dust emission dispersions in rock aggregate and natural stone quarries. Int J Surf Min Reclam Environ. doi:10.1080/17480930.2016.1271385

Salmela P, Selonen O, Palin H, (2014) Modern granite quarrying (Nykyaikaista graniitinlouhintaa). Vuorityö ja-tekniikka, pp 26-28 (in Finnish)

Selonen O, Heldal T (2003) Technologies. In: Selonen O, Suominen V (eds) Nordic Stone. Geological science series. UNESCO publishing, Paris, pp 42-50

Selonen O, Ehlers C, Luodes H, Lerssi J (2005) The Vehmaa rapakivi granite batholith - an assemblage of successive intrusions indicating a piston-type collapsing centre. Bull Geol Soc Finl 77:65-70

Selonen O, Ehlers C, Luodes H, Karell F (2011) Magmatic constraints on localization of natural stone deposits in the Vehmaa rapakivi granite batholith, southwestern Finland. Bull Geol Soc Finl 83:25-39 
Turnkey Instruments Ltd (2009) Osiris, Operating instructions. http://www.turnkey-instruments.com/images/documents/OsirisOperating-Instructions.pdf. Accessed 18 March 2014

Turnkey Instruments Ltd (2014) Topas \& Osiris, Environmental monitor, Training manual. http://www.turnkeyinstruments.com/images/documents/Topas-Osiris-Monitor-TrainingManual.pdf. Accessed 18 March 2014

US EPA (1995) AP 42, fifth edition, volume I chapter 13:

miscellaneous sources, http://www3.epa.gov/ttn/chief/ap42/ch13/final/c13s02.pdf. Accessed 2 Oct 2015

US EPA (2013) Air and radiation, six common pollutants, particulate matter PM, health. Last update 18 March 2013. http://www.epa.gov/airquality/particlepollution/health.html. Accessed 3 April 2014

Velleman (2009) WS 1080, Weather centre with touchscreen and pc interface, User manual

Vuolio R, Halonen T (2010) Räjäytystyöt (Blasting operations). Suomen rakennusmedia Oy. ISBN-13: 9789525785340, ISBN-10: 9525785343 (in Finnish)

World Health Organization (1999) Hazard Prevention and Control in the Work Environment: Airborne Dust. World Health Organization, Switzerland. WHO/SDE/OEH/99.14.

http://www.who.int/occupational_health/publications/en/oehairbornedust3.pd Accessed 6 Sept 2015 